\title{
The Reversal of Fortune Thesis Reconsidered*
}

\author{
Sanghamitra Bandyopadhyay and Elliott Green \\ Department of Economics and STICERD, \\ University of Birmingham and LSE. \\ and Development Studies Institute, LSE
}

The Suntory Centre

Suntory and Toyota International Centres for Economics and Related Disciplines

London School of Economics and Political Science Houghton Street

London WC2A 2AE

EOPP/2010/16

Tel: (020) 79556674

\footnotetext{
* We would like to thank Gareth Austin for comments and suggestions, James Robinson for sharing data with us and Frank Brumfit and Erika Macleod for research assistance. All errors, however remain our own.
} 


\begin{abstract}
Acemoglu, Johnson, \& Robinson (2002) have claimed that the world income distribution underwent a "Reversal of Fortune" from 1500 to the present, whereby formerly rich countries in what is now the developing world became poor while poor ones grew rich. We question their analysis with regard to both of their proxies for pre-modern income, namely urbanization and population density. First, an alternative measure of urbanization with more observations generates a positive (but not significant) correlation between pre-modern and contemporary income. Second, we show that their measure of population density as a proxy is highly flawed inasmuch as it does not properly measure density on arable land, and when corrected with better data the relationship is no longer robust. At best our results demonstrate a Reversal of Fortune only for the four neo-Europes of Australia, Canada, New Zealand and the United States; at worst, we show no Reversal for other former colonies.
\end{abstract}

Keywords: income distribution, population density, Reversal of Fortune, urbanization. 
This series is published by the Economic Organisation and Public Policy Programme (EOPP) located within the Suntory and Toyota International Centres for Economics and Related Disciplines (STICERD) at the London School of Economics and Political Science. This new series is an amalgamation of the Development Economics Discussion Papers and the Political Economy and Public Policy Discussion Papers. The programme was established in October 1998 as a successor to the Development Economics Research Programme. The work of the programme is mainly in the fields of development economics, public economics and political economy. It is directed by Maitreesh Ghatak. Oriana Bandiera, Robin Burgess, and Andrea Prat serve as codirectors, and associated faculty consist of Timothy Besley, Jean-Paul Faguet, Henrik Kleven, Valentino Larcinese, Gerard Padro i Miquel, Torsten Persson, Nicholas Stern, and Daniel M. Sturm. Further details about the programme and its work can be viewed on our web site at http://sticerd.lse.ac.uk/research/eopp.

Our Discussion Paper series is available to download at:

http://sticerd.lse.ac.uk/_new/publications/series.asp?prog=EOPP

For any other information relating to this series please contact Leila Alberici on:

Telephone: UK+20 79556674

Fax: $\quad$ UK+20 $\quad$ : $\quad$ (a556951

Email: $\quad$ l.alberici @lse.ac.uk

(C) The authors. All rights reserved. Short sections of text, not to exceed two paragraphs, may be quoted without explicit permission provided that full credit, including (C) notice, is given to the source. 


\section{Introduction}

In a seminal paper Acemoglu et al. (2002) argue that countries in the developing world have experienced a "Reversal of Fortune," whereby those which were previously rich in the pre-colonial era have become poor, while those that were poor are now rich. Rather than explaining this reversal through geographic factors, they claim that different sets of institutions imposed by colonial rule resulted in differing patterns of industrialization over the past two hundred years, and that this phenomenon happened across the colonial world, regardless of the nature of the colonial power. Their thesis has drawn a great deal of attention due to its strong emphasis on European colonial rule as the major explanation for divergence in the modern world income distribution.

Naturally the biggest problem with any analysis of long-term income trends is the lack of accurate data on pre-modern income levels. Acemoglu et al. (2002) (henceforth AJR) proxy for pre-modern income in two ways, namely urbanization and population density. In both cases they argue that a higher value represents a higher aggregate income inasmuch as only societies with high incomes could support urban and dense populations. ${ }^{1}$

In this paper, however, we question their data for these two proxies of precolonial income. First, their measure of urbanization contains no data from Africa and thus consists of only 41 observations; when we use an alternative measure of urbanization with 71 observations from Africa and the Americas the relationship disappears and even changes sign. Second, despite their claims to the contrary their data on population density does not properly account for arable land, and, when corrected with better data, their results collapse across a number of econometric specifications. We use standard Ordinary Least Squares regression approaches as done by AJR.

We therefore not only suggest that AJR's analysis does not hold on a global scale but offer two specific reasons for this result. First, in no specifications do the data show a reversal within Africa, thereby suggesting that Africa's poverty was largely untouched by colonialism. Secondly, the results are largely driven by the four Neo-Europes, which, when excluded, render the relationship between pre-colonial income and contemporary GDP per capita either weakly significant or not significant. Thus, while we do not rule out a Reversal of Fortune among select countries, our results suggest that whatever reversal took place was not a generalized phenomenon.

The rest of the paper is organized as follows. In Section 2, we describe

\footnotetext{
${ }^{1}$ Moreover, they are not alone in using these proxies; other recent literature to use one or both measures include Huillery (2009) and Oster (2004).
} 
the differences between AJR's data on urbanization and population density and ours. In Section 3 we present our new empirical results of regressing contemporary income levels on these two proxies of pre-modern incomes. We then offer an interpretation of the results in Section 4 and Section 5 concludes.

\section{Description of the Data}

\section{$2.1 \quad$ Urbanization}

The first proxy used by AJR for income in 1500 is urbanization, or more specifically the percentage of a given population living in cities. They use data on urbanization from Bairoch (1988) and Eggimann (1999) by supplementing Bairoch (1988)'s data on cities greater than 5000 people with Eggimann (1999)'s estimates of cities larger than 20,000 people and then converting Eggimann (1999)'s data to a 5000-person minimum. They claim in an earlier version that 5000 people is a much better threshold as it accounts for a greater number of small pre-modern cities (Acemoglu, Johnson, \& Robinson, 2001; Appendix A, p. 1).

However, it is no accident that both Chandler (1987) and Eggimann (1999) only list data on pre-modern cities greater than 20,000 people as the data on pre-modern urbanization in the developing world is remarkably poor. Indeed, Bairoch (1988, p. 520) himself notes that "given the current state of data and research, it is impossible in the case of most countries to assemble figures on urban population sufficiently complete to give a valid indication of the population of all cities with more than five thousand;" he indicated that his future efforts would be directed at lowering the population threshold to 8000 people for Europe. ${ }^{2}$ Historians agree that data on small ancient cities can be inaccurate for the reasons that abandoned cities can disappear over time, migration routes can make it difficult to measure cities' permanent populations and much archaeological work on ancient cities in the tropics remains to be done (Connah, 2001; Hopkins, 2009). Thus even Chandler (1987)'s comprehensive data lacks population figures for 18 of the 60 cities he identifies in Africa and the Americas in 1500.

To correct for these problems we use Chandler (1987)'s data on cities of 20,000 or more for Africa and the Americas. Far from being idiosyncratic, the 20,000 benchmark determinant for urbanization is currently used by such countries as Nigeria and was used for a period by the United Na-

\footnotetext{
${ }^{2}$ As acknowledged by Acemoglu et al. (2001, Appendix A, p. 1), Bairoch did not complete this work before he died in 1999, let alone move on to completing a dataset of all pre-modern cities greater than 5000 people.
} 
tions; economists and economic historians who have used it as well include Annable (1972), Berry (1961), Hoselitz (1957) and Long (2005), among others. Moreover, using Chandler (1987) as our source has several advantages. First, unlike AJR's use of both Bairoch (1988) and Eggimann (1999), all of our data originates from a single source. Second, by using data directly from its source we avoid the need to convert it and thereby open ourselves to criticism of the conversion process. ${ }^{3}$ Third and finally, this data allows us to include data on Africa in 1500 in our regressions. While AJR decided to exclude African data because they claim that it was not "detailed" enough (Acemoglu et al., 2002, p. 1238), Chandler (1987)'s data contains 43 cities in Africa for 1500, or more than twice as many as in the Americas (with 17 cities). Moreover, Chandler (1987, p. 6) himself notes that, thanks to 16thcentury data on African cities from Leo Africanus, "Africa at 1500 stands as one of the best-prepared lists in this book." While using Chandler (1987)'s data means that we lose our observations from Asia, where Chandler (1987) only lists cities larger than 40,000, by adding Africa we improve the number of observations from 41 in AJR to 71 here.

\subsection{Population Density}

The second proxy used by AJR for pre-modern income is population density. For their data AJR calculate population density on arable land for the simple reason that including non-arable land would make pre-modern states like ancient Egypt appear very thinly populated and thus not very rich. They take their data on arable land from McEvedy \& Jones (1978), with the claim that doing so "excludes primarily desert, inland water and tundra" (Acemoglu et al., 2002, p. 1243). However, while McEvedy \& Jones (1978) sometimes present data on arable land for various countries, in 78 of the 83 observations used in AJR they list no data on arable land, leading AJR to assume all land as arable for these observations. Yet this assumption is highly problematic in a large number of countries like Australia, Botswana and Canada which have large tracts of non-cultivable frozen tundra, deserts and mountains.

To correct for this error we employ here data from the FAO (2000), which for the first time estimated global data for land that is potentially arable (or potentially cultivable) for growing any one of twenty-one major crops under rainfed conditions, thus making it suitable for assessing population densities in 1500 when modern agricultural practices were not yet in use. Much of this potential arable land (henceforth PAL) are currently under

\footnotetext{
${ }^{3}$ For instance, AJR use Zipf's law as one way to convert the data, despite the fact that recent evidence suggests that Zipf's law does not apply widely across countries (Soo, 2005).
} 


\begin{tabular}{rlll}
\hline \hline Country & $\begin{array}{l}\text { Arable } \\
\text { Land }\end{array}$ & $\begin{array}{l}\text { Potential } \\
\text { Arable Land }\end{array}$ & $\begin{array}{l}\text { Equivalent Potential } \\
\text { Arable Land }\end{array}$ \\
\hline Canada & $100 \%$ & $12.7 \%$ & $7.7 \%$ \\
Botswana & 100 & 15.8 & 8.7 \\
Australia & 100 & 16.2 & 10.9 \\
South Africa & 100 & 23 & 14.7 \\
Laos & 100 & 25.4 & 15.9 \\
Kenya & 100 & 26.8 & 16.6 \\
Rwanda & 100 & 30 & 19 \\
New Zealand & 100 & 32.5 & 20.1 \\
USA & 100 & 37.5 & 28.5 \\
\hline \hline
\end{tabular}

Table 1: Selected Discrepancies in Arable Land Measurements, in percentages (Source: (Acemoglu et al., 2002; FAO, 2000))

pasture or constitute forests whose clearing would imperil local ecologies, but for simplicity's sake we assume that all PAL could be cultivated. We also examine a more stringent definition of PAL called "equivalent potential arable land" (EPAL) which downgrades marginal land proportional to its suitability for agriculture. ${ }^{4}$

We can see the differences between select countries estimated by AJR as having $100 \%$ of their land as arable and the FAO data in Table 1 . The disparities are stark, especially in neo-colonies and Africa. In fact, the FAO's estimates of PAL may be overly generous in some cases. For instance, the Canada Land Directory grades soil quality from level 1 to level 7, where levels 1-4 are suitable for permanent agriculture land, levels 5 and 6 are suitable for grazing and level 7 is land unsuitable for agriculture; it estimates that only $10.3 \%$ of Canada's land falls within levels 1-5, and only $5.0 \%$ within levels 1-3 (Canada Land Inventory, 1976). Similarly, the Botswanan Ministry of Agriculture estimated only $5.2 \%$ of its land to be cultivable in the $1970 \mathrm{~s}$, with only $1 \%$ of land under cultivation at any one point (Alverson, 1984). Thus, in at least these two cases, EPAL is a better reflection of cultivable land than PAL.

Another way to assess the accuracy of the FAO data is to compare it to those cases where McEvedy \& Jones (1978) compute arable land for given countries. ${ }^{5}$ For instance, AJR calculate only $11.4 \%$ of Sudan's land as cul-

\footnotetext{
${ }^{4}$ Where one hectare of very suitable, suitable, moderately suitable and marginal land are counted as 1.0, 0.7, 0.5 and 0.3 hectares, respectively.

${ }^{5}$ In fact, McEvedy \& Jones (1978) do not have a single metric like the FAO for potentially arable land; instead they variously list figures for "cultivated" (Egypt), "productive"
} 
tivable based on McEvedy \& Jones (1978)'s calculations of arable and pasture land - i.e., land already in some form of use by farmers or pastoralists. Yet, as elsewhere in Africa, Sudan has historically had low population densities that were not able to fully exploit its large tracts of cultivable land. Its large reserves of available fertile land contributed to its reputation in the 1970s as the potential "Breadbasket of the Middle East," which led to subsequent attempts to use land more productively despite ongoing war and poor governance. Thus the FAO's calculation of $867,000 \mathrm{Km} 2$ of PAL - or $35 \%$ of all land - is closer to other estimates of 840,000 and 810,000 Km2 from ElFarouk (1996) and Kaikati (1980), respectively, than the mere 300,000 km2 calculated by McEvedy \& Jones (1978). ${ }^{6}$

\section{Empirical Analysis}

With these new data on urbanization and arable land we can now re-estimate AJR's models. We should note, however, several changes to the dataset. First, eight Caribbean countries included in the AJR paper could not be included here due to a lack of data on potential arable land, namely the Bahamas, Barbados, Dominica, Grenada, St. Kitts and Nevis, St. Lucia, St. Vincent and Trinidad and Tobago. AJR also lack data on population densities for these countries, but assume that they have the same population density as the Dominican Republic. We could do the same here but see no reason why we should assume that these countries, which have a combined population of 2.4 million people, had population densities on potential arable land in 1500 closer to the Dominican Republic (PAL density of 3.2) than to Jamaica (32.1). Second, we have also included other former European colonies with a combined population of 41.5 million people that were inexplicably not included in the AJR analysis, namely Cambodia, Djibouti, Equatorial Guinea, Guinea-Bissau and Yemen. ${ }^{7}$ Third, inasmuch as the "Reversal of Fortune" argument involves the transition from pre-colonial occupation to colonial domination and then post-colonial independence, we exclude three countries included in AJR which should not have been in their analysis, namely Cape Verde (which had no human occupants prior to colonialization) and Ethiopia and Nepal (neither of which were colonized by

(Algeria, Morocco and Tunisia), and "pasture" and "arable" (Sudan) land. For more criticism of McEvedy \& Jones (1978) see Austin (2008b) and Hopkins (2009).

${ }^{6}$ Sudan's EPAL is $629,450 \mathrm{Km} 2$, which is still closer to these other estimates than the sum from McEvedy \& Jones (1978).

${ }^{7}$ As with AJR (p. 1244), we exclude from the analysis countries colonized in the 20th century for the reason that their colonial experience was too short to have an impact on long-term economic growth patterns. 
Europeans). Fourth and finally, we added countries which were colonized by Europeans after 1500 and lie in Europe, namely Cyprus (under UK administration 1878-1960) and Malta (UK administration, 1814-1964). Descriptive statistics for our variables are presented in Table 9 in the Appendix.

We also use three geographical controls in our analysis, namely average latitude, average distance to coastline and average elevation per country, which are similar to the control variables used by AJR. ${ }^{8}$

\subsection{Urbanization}

In Figures 1 and 2 we plot log GDP per capita in 1995 against the urbanization variable used by AJR and our new urbanization variable, CHANDLER, respectively. In Figure 1, the OLS fit suggests a negative relationship between the two variables. However, in Figure 2, the OLS fit suggests a positive relationship, but the fit is clearly very poor.

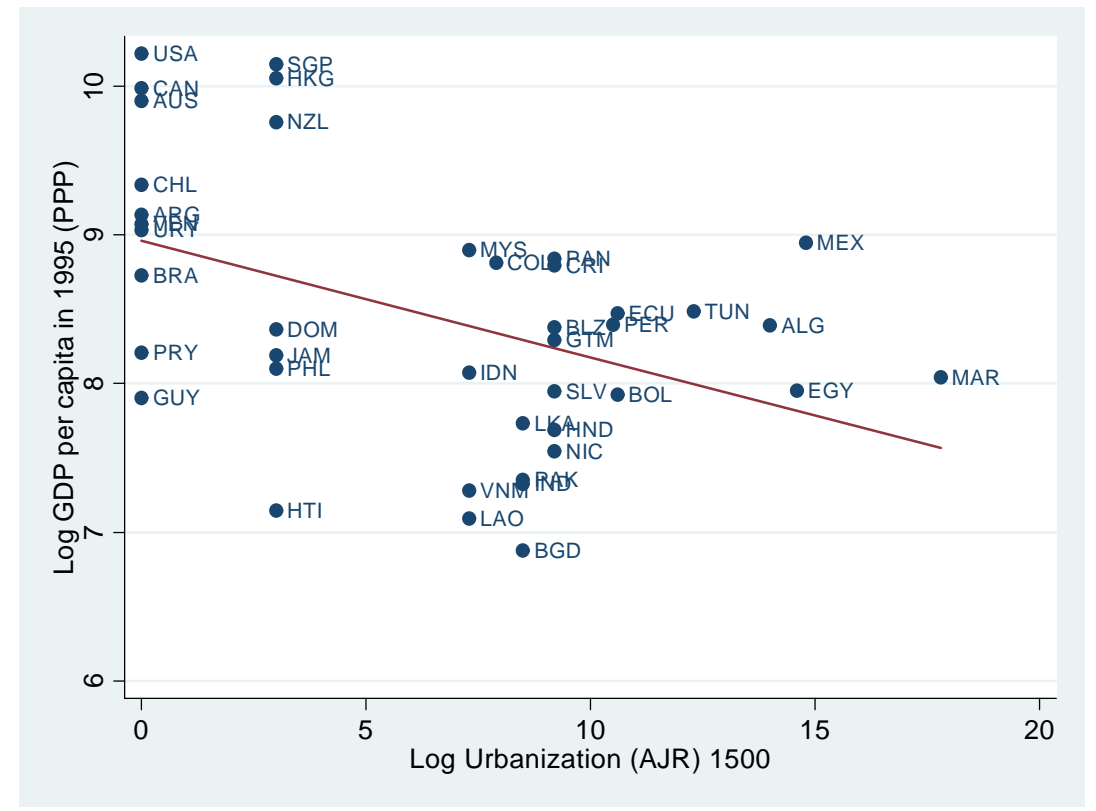

Figure 1: Log GDP per Capita (PPP) in 1995 against Urbanization Rate in 1500, AJR

\footnotetext{
${ }^{8}$ We have also used a number of other controls from the literature on long-term economic growth patterns (Bockstette et al., 2002; Easterly and Levine, 2003; Olsson and Hibbs, 2005; Putterman, 2008), with no changes in our results.
} 


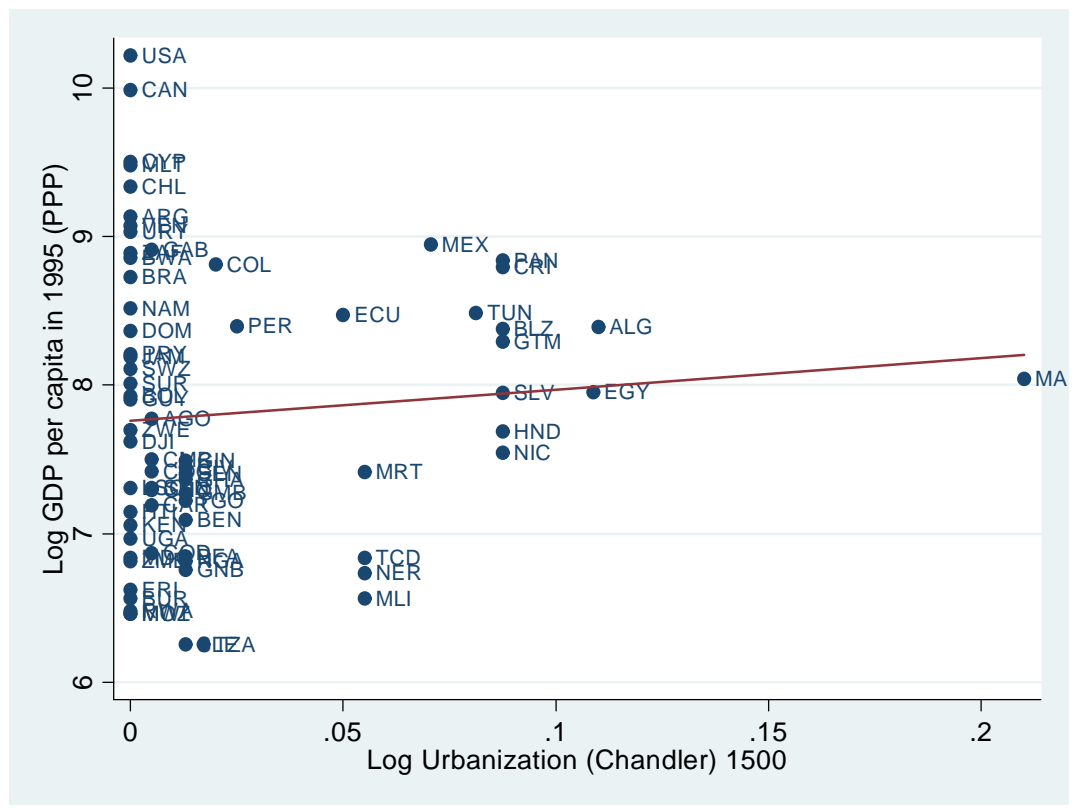

Figure 2: Log GDP per Capita (PPP) in 1995 against Urbanization Rate in 1500, Chandler

In Table 2, we present the results for OLS regressions of log GDP per capita (PPP) in 1995 on urbanization. The basic model we estimate is:

$$
G D P_{i}=\alpha+\beta \text { Urbanization }_{i}+\varepsilon_{i}
$$

where $G D P_{i}$ is $\log$ GDP per capita (PPP) in 1995 for country $i$, Urbanization $_{i}$ is the Chandler urbanization estimate for country $i$, and $\varepsilon_{i}$ is an error term assumed to be normally distributed. In Panel A we present the results with the full sample and the continent sub-samples. The first column records the result with the urbanization variable used by AJR, yielding a negative and significant coefficient. In column 2 (and all columns hereafter) we use the Chandler urbanization variable and find that the urbanization coefficient is positive and no longer significant in our full sample. In column 3 we re-run the regression after dropping observerations with urbanization equal to zero and find a positive and significant relationship. This result suggests that, for those countries which had some level of urbanization in 1500, there exists a positive relationship between income per-capita in 1500 and 1995, albeit one which is not robust to our three geographical controls (not reported here). ${ }^{9}$

\footnotetext{
${ }^{9}$ Namely, average latitude, average distance to coastline and average elevation per country.
} 
When we split the sample by continents, as also done by AJR, we obtain different results for each continent group. We find that the relationship remains significant for the Africa sub-sample (column 4), although this result is not significant upon adding geographical controls (not reported here). Column 5 demonstrates a weakly significant and negative coefficient in the sample excluding Africa; however, as before the coefficient is not significant after the controls are added (also not reported). We also present results in columns 6-9 for sub-samples excluding the Neo-Europes (Canada and the US only, as our data does not include Australia and New Zealand), and for subsamples of former French, Spanish and British colonies. We obtain a weakly positive and significant relationship between urbanization and log GDP for the sample excluding the Neo-Europes, and an insignificant relationship in all other sub-samples. We also test for a sub-sample of former British colonies excluding the two Neo-Europes (not reported here), with similar results. ${ }^{10}$

To check to see if we are ignoring smaller cities, we can assume that the aforementioned 18 cities listed by Chandler (1987) for Africa and the Americas that do not have population figures have the minimum level of 20,000 people per city. We rerun our regressions, presented in Panel B; for none of the sub-samples do we obtain a negative and significant coefficient for the Urbanization Max variable. The only differences between Panels A and $\mathrm{B}$ are that the sub-sample excluding zero values for urbanization, our Africa sub-sample and without Africa sub-sample regressions lose some of their significance.

\footnotetext{
${ }^{10}$ This sub-sample thus includes such countries as Guyana, India, Jamaica, Kenya and Zimbabwe, among others.
} 


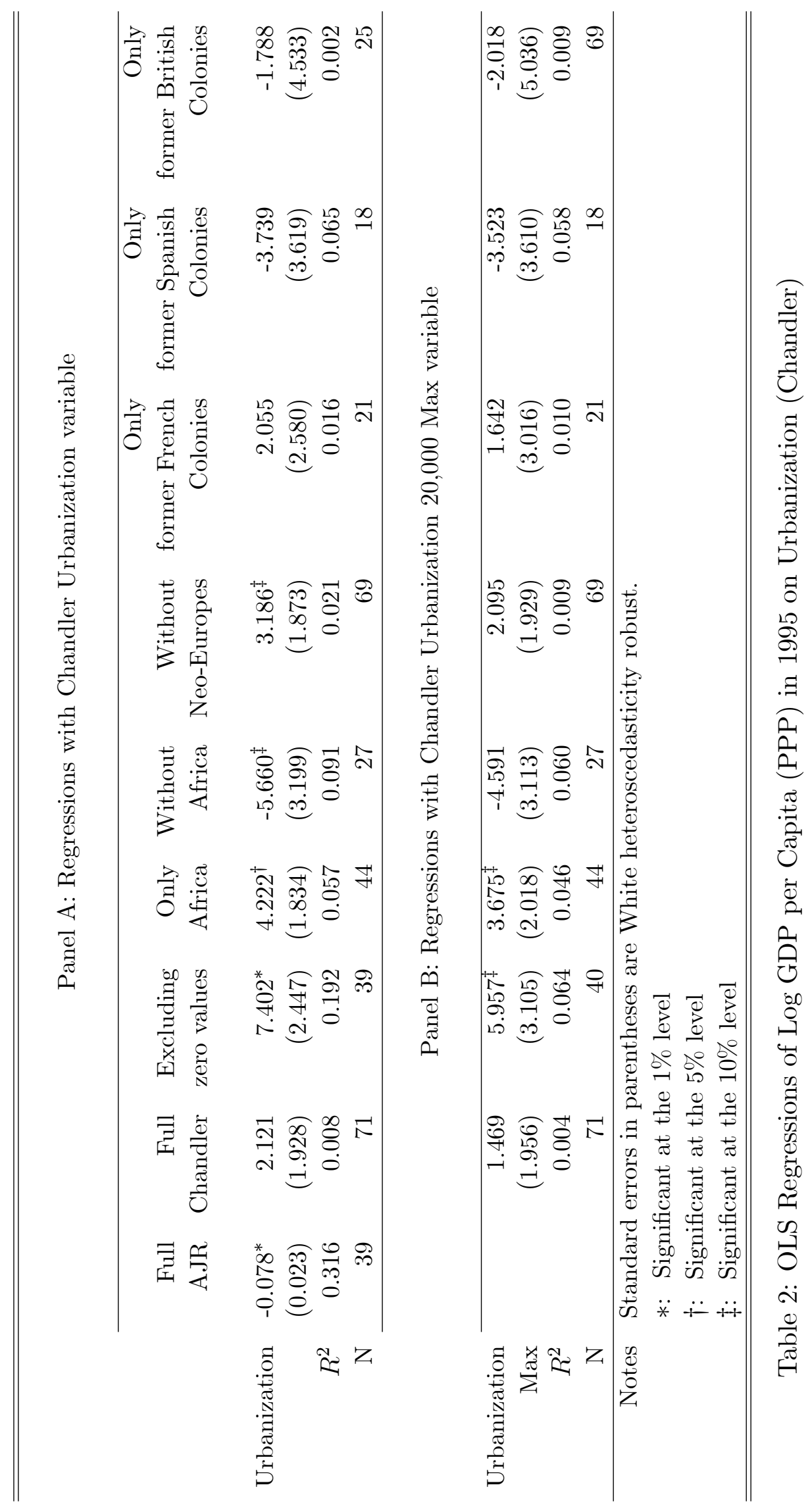


Thus, in using the Chandler definition of urbanization we observe that the Reversal of Fortune result obtained by AJR does not hold. To summarize our findings:

- The relationship between urbanization and log GDP per capita is not significant for the (African and American) full sample and all but one sub-sample.

- The relationship is positive and significant for the sub-samples excluding zero values of urbanization and for our Africa sub-sample. However, this result is not robust to the inclusion of geographical controls.

- These results hold whether we include or exclude the 18 cities listed by Chandler (1987) that do not have population figures.

\subsection{Population Density}

In this section we observe the relationship between population density and log GDP. The results obtained here are mixed compared to what we obtained using the urbanization variable. The following figures plot log GDP per capita in 1995 against population density in 1500; first, in Figure 3 for population density variable used by AJR, and in Figure 4 for our new population density variable, PAL. We observe a clear negative relationship in Figure 3. However, in Figure 4, while the plot generates a similar negative sloping OLS fit, it appears to be driven by specific data points. To isolate the effects of certain countries, we will therefore not just test for the relationship using the full sample data, but using sub-samples of countries, described below.We estimate OLS regressions of log GDP per capita (PPP) in 1995 on our new population density variables. The basic model we estimate is:

$$
G D P_{i}=\gamma+\theta \text { PopulationDensity }{ }_{i}+\epsilon_{i}
$$

where $G D P_{i}$ is $\log$ GDP per capita (PPP) in 1995 for country $i$, PopulationDensity $_{i}$ is the population density estimate for country $i$, and $\epsilon_{i}$ is an error term assumed to be normally distributed. Table 3 presents the results for the continent specific sub-samples and the former colony sub-samples. In Panel A columns 1 and 2 present the results with the AJR definition of population density and the FAO corrected-definition of population density, respectively. While in both cases there is a negative and significant relationship, the size of the coefficient for the FAO population density variable is less than half of the coefficient of the AJR variable. Moreover, the goodness of fit (the $R^{2}$ ) of the FAO variable regression is less than a third than that of the AJR 


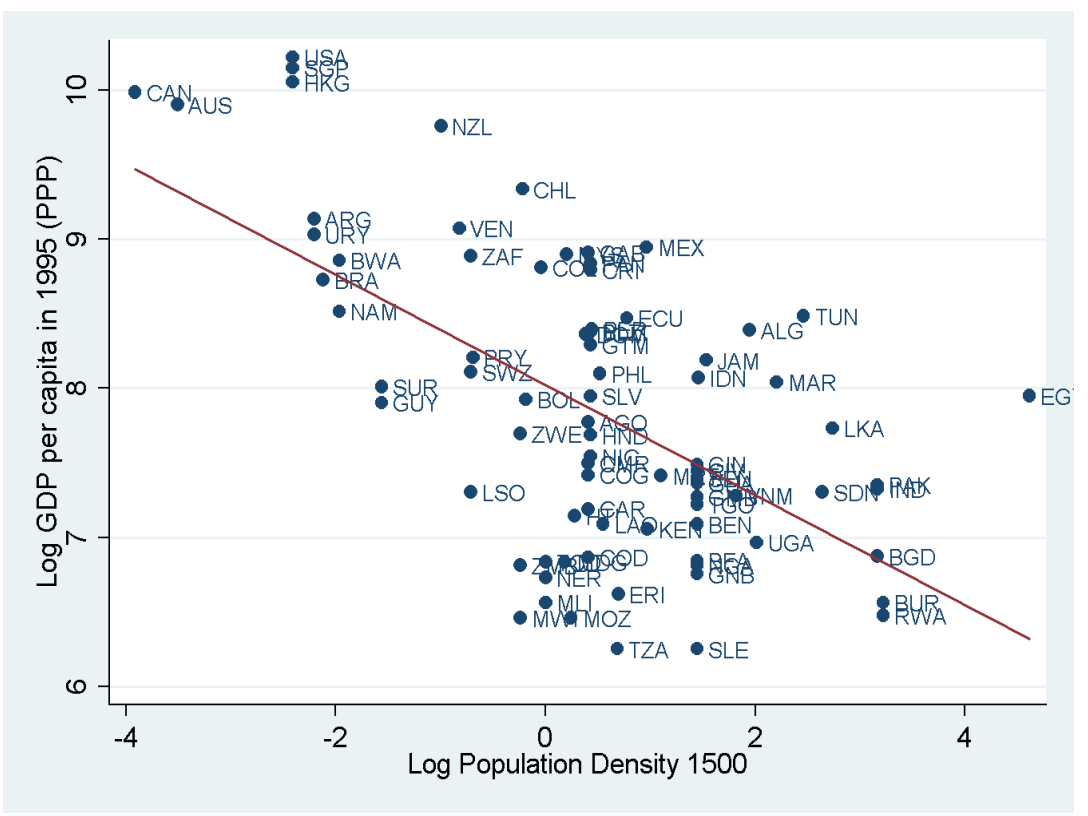

Figure 3: Log GDP per Capita (PPP) against Log Population Density in 1500, AJR

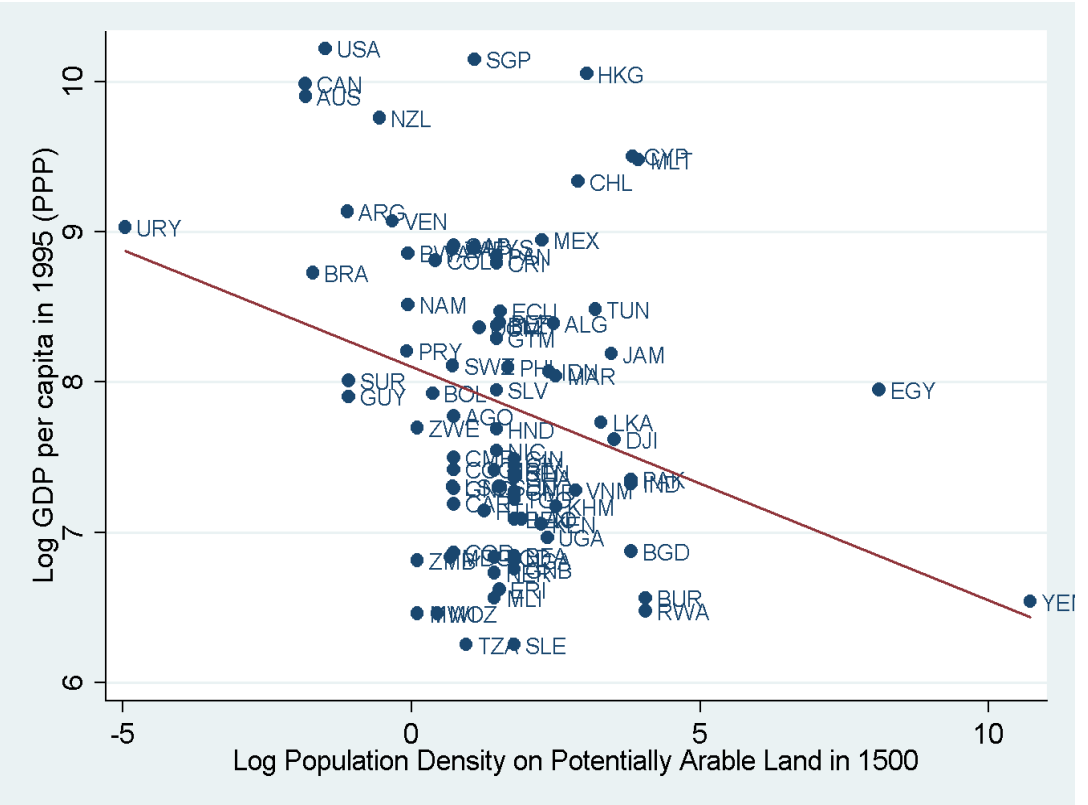

Figure 4: Log GDP per Capita (PPP) against Log Population Density in 1500, FAO 
variable regression. Column 3 presents the results with the FAO variable and geography controls, and the relationship remains negative and significant. However, the following sub-samples obtain mixed results. While the coefficient is negative and strongly significant for the sample without Africa (column 4), it is not significant for only Africa (column 5). For the sample without the Americas in column 6 the relationship is again not significant, and barely significant for the sample with only the Americas (Column 7).

In Panel B we present the regressions with the former colony sub-samples. While AJR find that for the sample excluding the four Neo-Europes results in a significant relationship (t-statistic $=5.33)^{11}$, in our sample the same subsample generates a barely significant relationship (with t-statistic $=1.9$ ). The relationship is not significant for former French and Spanish colonies in columns 2 and 3, respectively. In column 4 the relationship is again signficant for former British colonies, but becomes insignificant when the Neo-Europes are dropped from the sub-sample in column 5.

For robustness, we run the same regressions using EPAL. We observe a similar set of relationships between population density and log GDP in Table 4. In the full sample equivalent population density has a negative and significant relationship with log GDP, with similar results for the sub-sample without Africa; however it is not significant in the sub-samples of only Africa and without the Americas. When excluding Neo-Europes it is again weakly significant and is not significant for sub-samples of former French and Spanish colonies, and former British colonies excluding the Neo-Europes.

As with AJR we also estimate the above regressions using population density per kilometer of potential arable land in the year 1000 as an instrument for PAL. Table 5 lists our Two Stage Least Squares (2SLS) results, which correspond exactly to the same results we found with the PAL and EPAL variables previously. The relationship is negative and significant for the full sample but not for most of the sub-samples.

${ }^{11}$ Table V, p. 1250, Acemoglu et al (2002). 


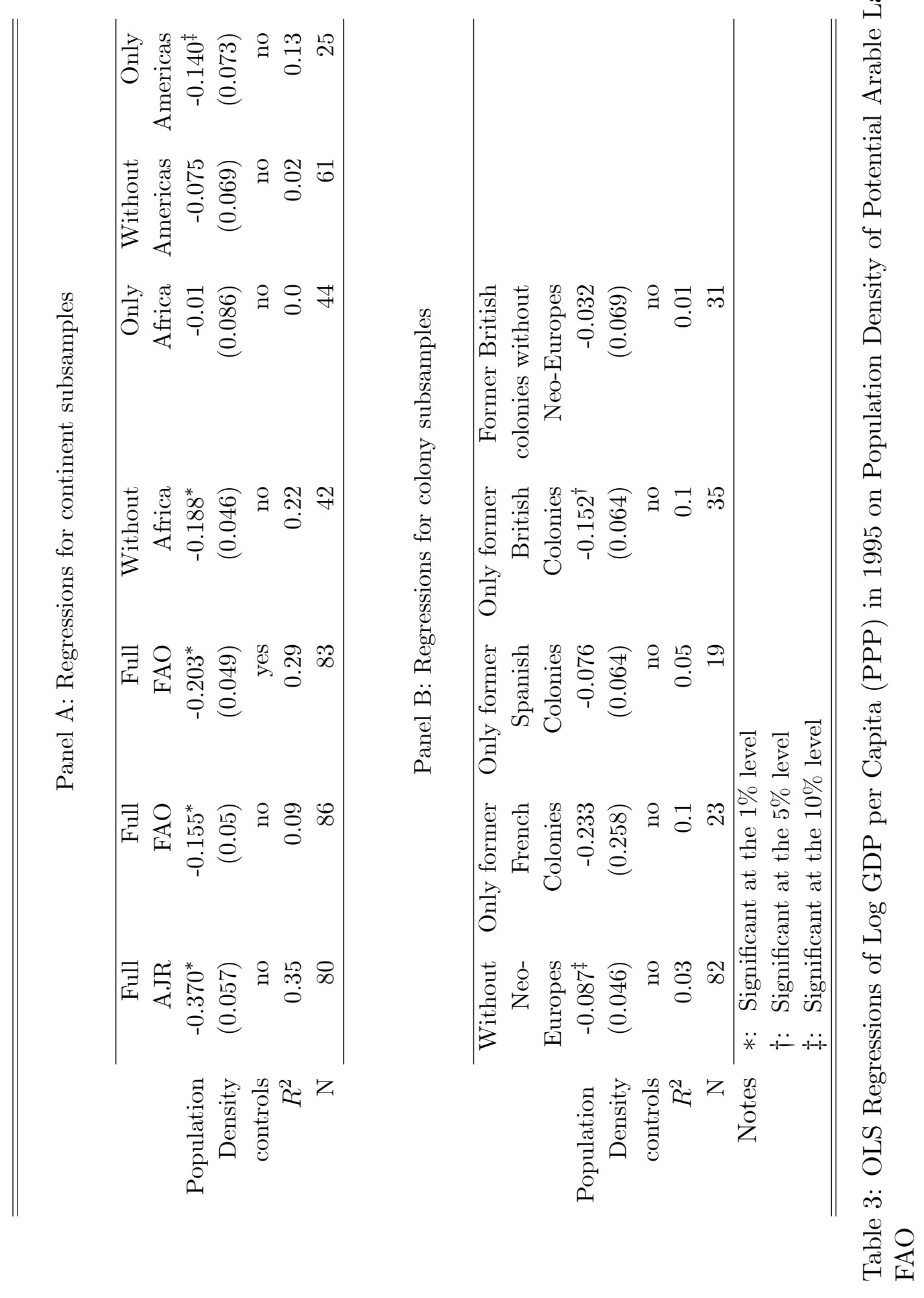




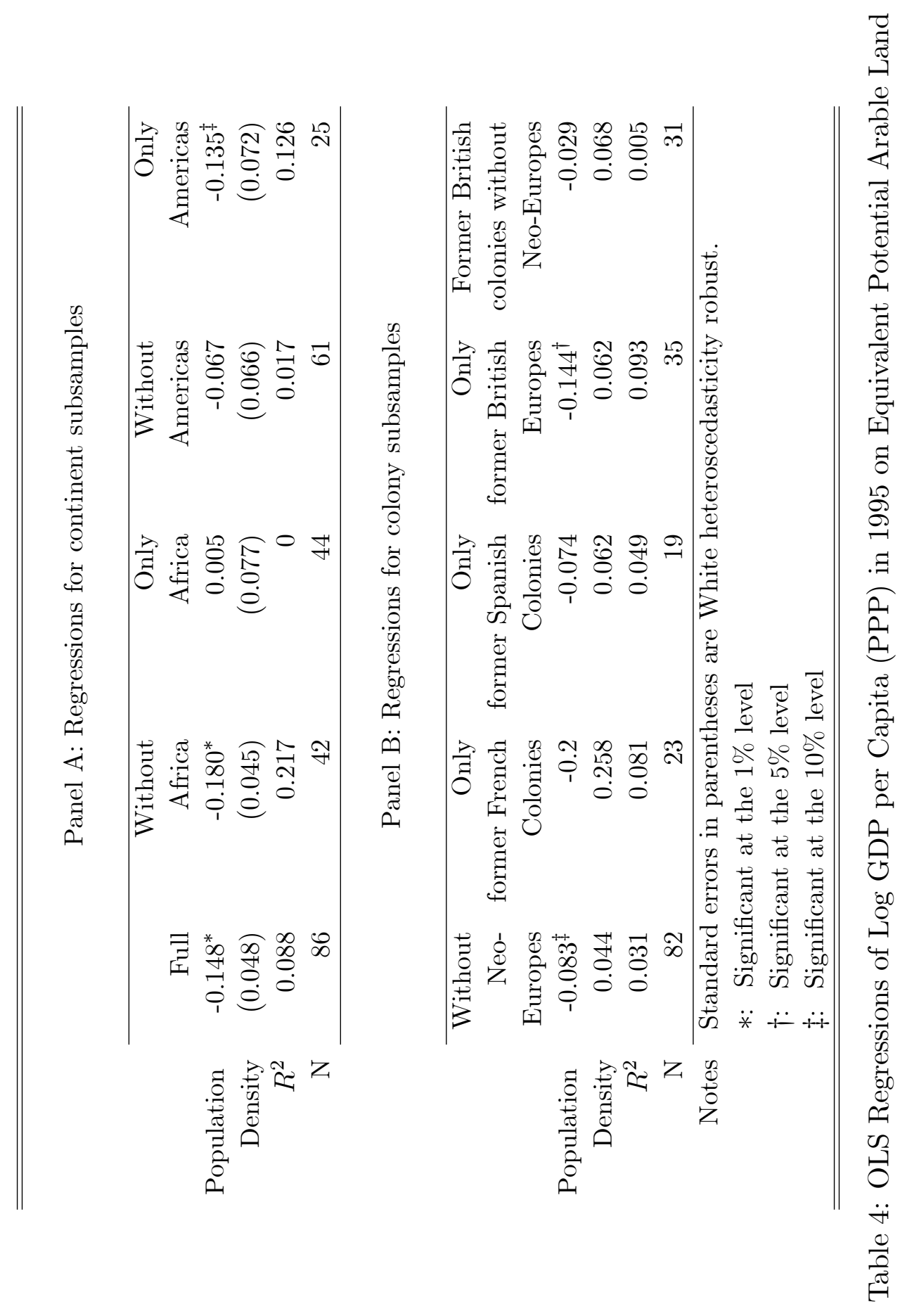




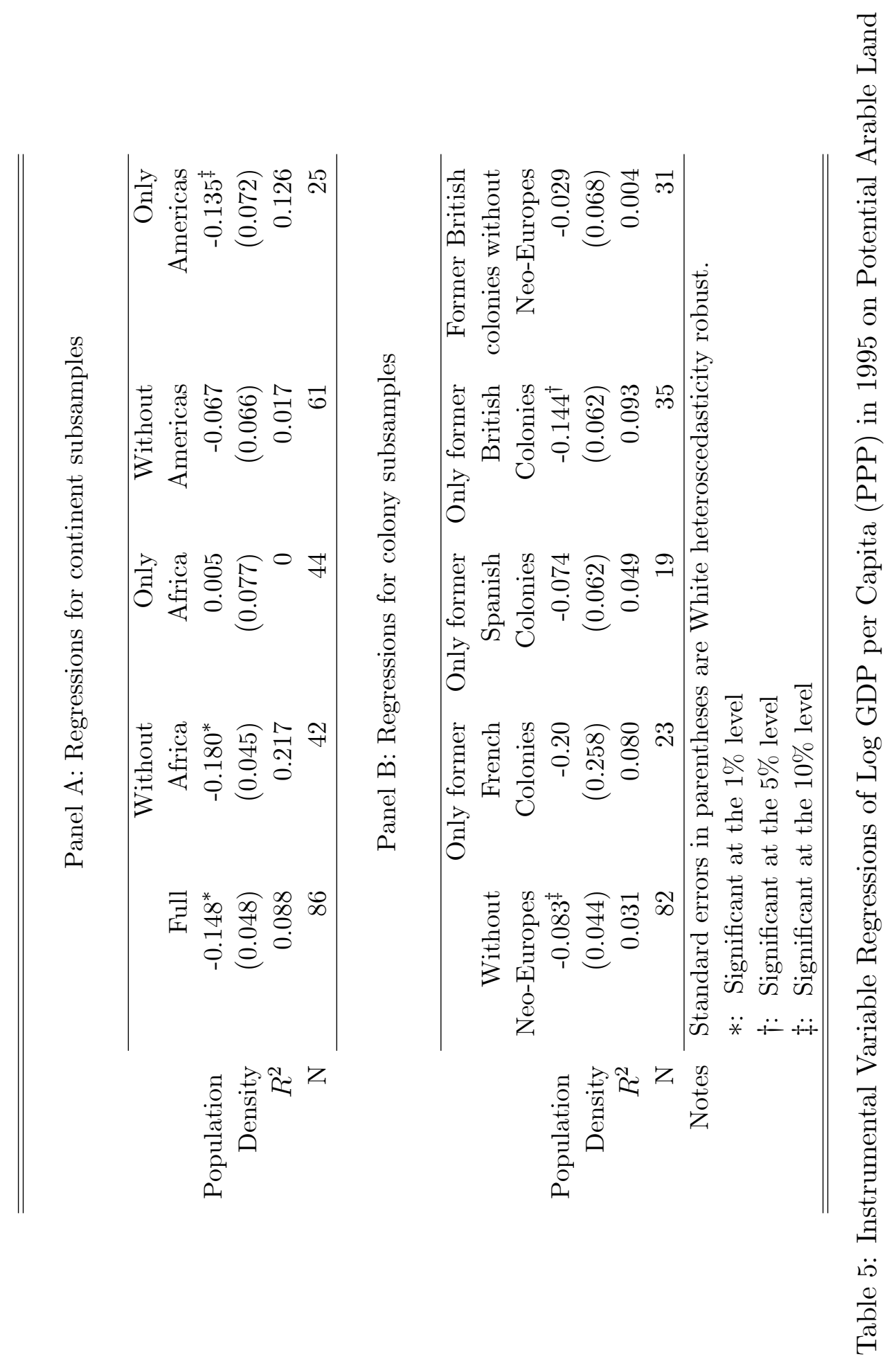


Our results in Tables 3 - 5 thus suggest that the relationship between population density in 1500 and contemoprary GDP per capita is not robust.

We can now summarise our findings:

- The relationship between population density and log GDP per capita is negative and significant for the full sample, the sample excluding Africa, and the sample with former British colonies.

- It is weakly significant for the sample of the Americas and the sample excluding the Neo-Europes.

- It is not significant for the sub-samples of Africa, the sample excluding the Americas and the sub-samples of former French, Spanish, and British colonies excluding the Neo-Europes.

- Our results are robust for both the PAL and EPAL variables, and the IV regressions.

\section{Interpretation}

In using new population density and urbanization data we find two consistent results. First, the data suggests that the Reversal of Fortune thesis fails to work for African countries, which together comprise a majority of our and AJR's sample. This finding adds to and corresponds with a long literature on Africa which suggests that the continent was already poor before the advent of formal colonialism in the late 19th century, whether due to the slave trade (Nunn, 2008), low population densities (Austin, 2008a; Green, 2010), malaria (Bhattacharyya, 2009; Bloom \& Sachs, 1998) or ethnic diversity (Birchenall, 2009; Easterly \& Levine, 1997), among other possible factors. It also corresponds to a recent literature suggesting an ambiguous and sometimes positive effect of colonial rule on development in Africa, especially as regards population growth, height and nutrition (Clapham, 2006; Moradi, 2009). As suggested by (Hopkins, 2009), more work on African economic history is thus necessary to help tease out the effects of colonialism on long-term economic growth.

Our second consistent finding is a lack of a reversal among former French and Spanish colonies, accounting for $49 \%$ of the sample. While we can explain the former case by the fact that 19 of 23 former French colonies were in Africa, only 2 of 19 former Spanish colonies were outside the Americas. ${ }^{12}$

\footnotetext{
${ }^{12}$ Namely, Equatorial Guinea and the Philippines.
} 
This disparity among colonial powers is not surprising, however, considering the voluminous literature on the different effects of colonial powers on post-colonial economic and political development (Bertocchi \& Canova, 2002; Blanton, Mason, \& Athow, 2001; Grier, 1999; Lange, Mahoney, \& Vom Hau, 2006). There is some evidence in our results that this disparity is a result of the Neo-Europes, but, as with our results for Africa, this remains a topic for further investigation.

\section{Conclusion}

This paper has questioned the empirical analysis of AJR's Reversal of Fortune thesis, specifically as regards their use of both pre-colonial urbanization and population density as proxies for pre-modern income. We found in both cases that alternative and more appropriate measurements of both proxies fail to generate a robust negative relationship between income in 1500 and contemporary GDP per capita with appropriate levels of statistical significance, and in the case of urbanization the coefficient even changes signs to suggest a positive relationship.

With our urbanization data we did not find any strong evidence of the Reversal thesis for either our full sample of countries or any of our sub-samples. With our population density variables our full sample supported the Reversal thesis but several sub-samples did not, namely those that exclude the Americas and include only African countries, former French and Spanish colonies and former British colonies without Neo-Europes. At best these results suggest that a Reversal took place among certain countries, especially in the Neo-Europes; at worst our results suggest a total lack of a Reversal among most countries in our sample.

Our point here is not to suggest that the Reversal of Fortune argument is entirely incorrect. There exists a great deal of evidence to suggest that India, for instance, had higher wages than many parts of western Europe in the 16 th and 17th centuries, but that over the next three centuries Indian wages dropped while European wages increased dramatically (Allen, 2005). Other recent more qualitative work on the subject has agreed with certain aspects of the Reversal hypothesis even though it suggests alternative mechanisms (Bayly, 2008; Lange et al., 2006). Our evidence, however, suggests that that this Reversal was not a global phenomenon, especially in Africa and among former French and Spanish colonies. This result is also in line with Przeworski (2004)'s critique of AJR where he observes a Reversal only for the four Neo-Europes (or what he calls the "British off-shoots"). Certainly future scholars would benefit from further investigations into the nature of 
this Reversal and its causes.

\section{References}

[1] Acemoglu, D., Johnson, S., \& Robinson, J. A. (2001). Reversal of Fortune: Geography and Institutions in the Making of the World Income Distribution. NBER Working Paper \#8460.

[2] Acemoglu, D., Johnson, S., \& Robinson, J. A. (2002). Reversal of Fortune: Geography and Institutions in the Making of the Modern World Income Distribution. Quarterly Journal of Economics, 117(4), 1231-1294.

[3] Allen, R. C. (2005). Real Wages in Europe and Asia: A First Look at the Long-Term Patterns. In R. C. Allen, T. Bengtsson \& M. Dribe (Eds.), Living Standards in the Past (pp. 111-130). Oxford: Oxford University Press.

[4] Alverson, H. (1984). The Wisdom of Tradition in the Development of Dry-Land Farming: Botswana. Human Organization, 43(1), 1-8.

[5] Annable, J. E. (1972). Internal Migration and Urban Unemployment in Low-Income Countries: A Problem in Simlutaneous Equations. Oxford Economic Papers, 24(3), 399-412.

[6] Austin, G. (2008a). Resources, Techniques and Strategies South of the Sahara: Revising the Factor Endowments Perspective on African Economic Development, 1500-2000. Economic History Review, 61(3), 587-624.

[7] Austin, G. (2008b). The 'Reversal of Fortune' Thesis and the Compression of History: Perspectives from African and Comparative Economic History. Journal of International Development, 20(8), 9961027.

[8] Bairoch, P. (1988). Cities and Economic Development: From the Dawn of History to the Present. Chicago: University of Chicago Press.

[9] Bayly, C. (2008). Indigenous and Colonial Origins of Comparative Economic Development: The Case of Colonial India and Africa. Policy Research Working Paper \#4474, World Bank.

[10] Bernhard, M., Reenock, C., \& Nordstrom, T. (2004). The Legacy of Western Overseas Colonialism on Democratic Survival. International Studies Quarterly, 48(1), 225-250. 
[11] Berry, B. J. L. (1961). City Size Distributions and Economic Development. Economic Development and Cultural Change, 9(4), 573-588.

[12] Bertocchi, G., \& Canova, F. (2002). Did Colonization Matter for Growth? An Empirical Investigation into the Historical Causes of Africa's Underdevelopment. European Economic Review, 46(10), 1851-1871.

[13] Bhattacharyya, S. (2009). Root Causes of African Underdevelopment. Journal of African Economies, 18(5), 745-780.

[14] Birchenall, J. A. (2009). Quantitative Aspects of Africa's Past Economic Development. Department of Economics, University of California at Santa Barbara.

[15] Blanton, R., Mason, T. D., \& Athow, B. (2001). Colonial Style and Post-Colonial Ethnic Conflict in Africa. Journal of Peace Research, 38(4), 473-492.

[16] Bloom, D. E., \& Sachs, J. D. (1998). Geography, Demography and Economic Growth in Africa. Brookings Journal on Economic Activity, $2,207-295$.

[17] Bockstette, V, Chanda, A., \& Putterman, L. (2002). States and Markets: The Advantage of an Early Start. Journal of Economic Growth, 7(4), 347-369.

[18] Canada Land Inventory. (1976). Land Capability for Agriculture, Preliminary Report. Environment Canada, Lands Directorate.

[19] Chandler, T. (1987). Four Thousand Years of Urban Growth: An Historical Census. Lewiston, NY: St. David's University Press.

[20] Clapham, C. (2006). The Political Economy of African Population Change. Population and Development Review, 32(Supplement), 96114 .

[21] Connah, G. (2001). African Civilizations: An Archaeological Perspective (2 ed.). Cambridge: Cambridge University Press.

[22] Easterly, W. R., \& Levine, R. (1997). Africa's Growth Tragedy: Policies and Ethnic Divisions. Quarterly Journal of Economics, 112(4), 12031250 .

[23] Easterly, W. R., \& Levine, R. (2003). Tropics, Germs, and Crops: How Endowments Influence Economic Development. Journal of Monetary Economics, 50(1), 3-40. 
[24] Eggimann, G. (1999). La Population des villes des Tiers-Mondes, 1500-1950. Geneva: Centre d'histoire economique Internationale de l'Universite de Geneve.

[25] El-Farouk, A. E. (1996). Economic and Social Impact of Environmental Degradation in Sudanese Forestry and Agriculture. British Journal of Middle Eastern Studies, 23(2), 167-182.

[26] FAO. (2000). Land Resource Potential and Constraints at Regional and Country Levels. Rome: Food and Agricultural Organization of the United Nations.

[27] Firmin-Sellers, K. (2000). Institutions, Context and Outcomes: Explaining French and British Rule in West Africa. Comparative Politics, $32(3), 253-272$.

[28] Green, E. (2010). Demographic Change and Conflict in Contemporary Africa. In Political Demography: Identity, Conflict and Institutions, edited by Jack A. Goldstone, Eric Kaufman and Monica Duffy Toft (New York: Palgrave-Macmillan).

[29] Grier, R. M. (1999). Colonial Legacies and Economic Growth. Public Choice, 98, 317-335.

[30] Hopkins, A. G. (2009). The New Economic History of Africa. Journal of African History, 50(2), 155-177.

[31] Hoselitz, B. F. (1957). Urbanization and Economic Growth in Asia. Economic Development and Cultural Change, 6(1), 42-54.

[32] Huillery, E. (2009). History Matters: The Long-Term Impact of Colonial Public Investments in French West Africa. American Economic Journal: Applied Economics, 1(2), 176-215.

[33] Kaikati, J. G. (1980). The Economy of the Sudan: A Potential Breadbasket of the Arab World? International Journal of Middle East Studies, 11(1), 99-123.

[34] Lange, M., Mahoney, J., \& Vom Hau, M. (2006). Colonialism and Development: A Comparative Analysis of Spanish and British Colonies. American Journal of Sociology, 111(5), 1412-1462.

[35] Long, J. (2005). Rural-Urban Migration and Socioeconomic Mobility in Victorian Britain. Journal of Economic History, 65(1), 1-35.

[36] McEvedy, C., \& Jones, R. (1978). Atlas of World Population History. New York: Penguin. 
[37] Moradi, A. (2009). Towards an Objective Account of Nutrition and Health in Colonial Kenya: A Study of Stature in African Army Recruits and Civilians, 1880-1980. Journal of Economic History, 69(3), 719-754.

[38] Nunn, N. (2008). The Long Term Effects of Africa's Slave Trade. Quarterly Journal of Economics, 123(1), 139-176.

[39] Olsson, O., \& Hibbs, D. (2005). Biogeography and Long-Run Economic Development. European Economic Review, 49(4), 909-938.

[40] Oster, E. (2004). Witchcraft, Weather and Economic Growth in Renaissance Europe. Journal of Economic Perspectives, 18(1), 215-228.

[41] Przeworski, P. (2004). Geography vs. Institutions Revisited: Were Fortunes Reversed? Mimeo, New York University.

[42] Putterman, L. (2008). Agriculture, Diffusion and Development: Ripple Effects of the Neolithic Revolution. Economica, 75(300), 729-748.

[43] Soo, K. T. (2005). Zipf's Law for Cities: A Cross-Country Investigation. Regional Science and Urban Economics, 35(3), 239-263. 


\begin{tabular}{|c|c|c|c|c|c|}
\hline & Urban (\%) & Urban (\%) & $\begin{array}{r}\text { Population } \\
\text { Density }\end{array}$ & $\begin{array}{l}\text { Population } \\
\text { Density }\end{array}$ & $\begin{array}{r}\text { Population } \\
\text { Density } \\
\text { EPAI }\end{array}$ \\
\hline Country & AJR & Chandler & & & \\
\hline Algeria & 14 & 11.0 & 7.0 & 11.7 & 19.6 \\
\hline Angola & & 0.5 & 1.5 & 2.1 & 3.1 \\
\hline Argentina & 0 & 0.0 & 0.1 & 0.3 & 0.4 \\
\hline Australia & 0 & & 0.0 & 0.2 & 0.2 \\
\hline Bangladesh & 8.5 & & 23.7 & 45.2 & 55.4 \\
\hline Belize & 9.2 & 8.8 & 1.5 & 4.4 & 6.5 \\
\hline Benin & & 1.3 & 4.2 & 6.0 & 8.3 \\
\hline Bolivia & 10.6 & 0.0 & 0.8 & 1.5 & 2.0 \\
\hline Botswana & & 0.0 & 0.1 & 1.0 & 1.7 \\
\hline Brazil & 0 & 0.0 & 0.1 & 0.2 & 0.3 \\
\hline Burkina Faso & & 1.3 & 4.2 & 6.0 & 8.3 \\
\hline Burundi & & 0.0 & 25.0 & 57.9 & 94.3 \\
\hline Cambodia & & & & 12.3 & 16.3 \\
\hline Cameroon & & 0.5 & 1.5 & 2.1 & 3.1 \\
\hline Canada & 0 & 0.0 & 0.0 & 0.2 & 0.3 \\
\hline CAR & & 0.5 & 1.5 & 2.1 & 3.1 \\
\hline Chad & & 5.5 & 1.0 & 4.2 & 6.3 \\
\hline Chile & 0 & 0.0 & 0.8 & 18.0 & 30.0 \\
\hline Colombia & 7.9 & 2.0 & 1.0 & 1.5 & 2.1 \\
\hline Congo D. R. & & 0.5 & 1.5 & 2.1 & 3.1 \\
\hline Congo Rep. & & 0.5 & 1.5 & 2.1 & 3.1 \\
\hline Costa Rica & 9.2 & 8.8 & 1.5 & 4.4 & 6.5 \\
\hline Cote d'Ivoire & & 1.3 & 4.2 & 6.0 & 8.3 \\
\hline Cyprus & & 0.0 & & 46.2 & 79.4 \\
\hline Djibouti & & 0.0 & & 33.6 & 78.7 \\
\hline Dominican Rep. & 3 & 0.0 & 1.5 & 3.2 & 4.9 \\
\hline Ecuador & 10.6 & 5.0 & 2.2 & 4.7 & 6.5 \\
\hline Egypt & 14.6 & 10.9 & 100.5 & 3305.8 & 6779.7 \\
\hline El Salvador & 9.2 & 8.8 & 1.5 & 4.4 & 6.5 \\
\hline Eq. Guinea & & 0.5 & & 2.1 & 3.1 \\
\hline Eritrea & & 0.0 & 2.0 & 4.6 & 6.8 \\
\hline Gabon & & 0.5 & 1.5 & 2.1 & 3.1 \\
\hline Gambia & & 1.3 & 4.2 & 6.0 & 8.3 \\
\hline Ghana & & 1.3 & 4.2 & 6.0 & 8.3 \\
\hline Guatemala & 9.2 & 8.8 & 1.5 & 4.4 & 6.5 \\
\hline Guinea & & 1.3 & 4.2 & 6.0 & 8.3 \\
\hline Guinea-Bissau & & 1.3 & 4.2 & 6.0 & 8.3 \\
\hline Guyana & 0 & 0.0 & 0.2 & 0.3 & 0.5 \\
\hline
\end{tabular}

Table 6: Appendix A: Urbanization and Population Density in 1500 


\begin{tabular}{|c|c|c|c|c|c|}
\hline & Urban (\%) & Urban (\%) & $\begin{array}{r}\text { Population } \\
\text { Density }\end{array}$ & $\begin{array}{r}\text { Population } \\
\text { Density }\end{array}$ & $\begin{array}{r}\text { Population } \\
\text { Density }\end{array}$ \\
\hline Country & AJR & Chandler & AJR & PAL & EPAL \\
\hline Haiti & 3 & 0.0 & 1.3 & 3.5 & 5.9 \\
\hline Honduras & 9.2 & 8.8 & 1.5 & 4.4 & 6.5 \\
\hline Hong Kong & 3 & & 0.1 & 20.8 & 29.4 \\
\hline India & 8.5 & & 23.7 & 45.2 & 55.4 \\
\hline Indonesia & 7.3 & & 4.3 & 10.9 & 15.7 \\
\hline Jamaica & 3 & 0.0 & 4.6 & 32.1 & 46.3 \\
\hline Kenya & & 0.0 & 2.6 & 9.5 & 15.3 \\
\hline Laos & 7.3 & & 1.7 & 6.8 & 10.9 \\
\hline Lesotho & & 0.0 & 0.5 & 2.1 & 3.2 \\
\hline Madagascar & & 0.0 & 1.2 & 2.0 & 3.1 \\
\hline Malawi & & 0.0 & 0.8 & 1.1 & 1.7 \\
\hline Malaysia & 7.3 & & 1.2 & 3.0 & 4.2 \\
\hline Mali & & 5.5 & 1.0 & 4.2 & 6.3 \\
\hline Malta & & 0.0 & & 51.3 & 76.9 \\
\hline Mauritania & & 5.5 & 3.0 & 4.2 & 6.3 \\
\hline Mexico & 14.8 & 7.1 & 2.6 & 9.6 & 13.7 \\
\hline Morocco & 17.8 & 21.0 & 9.1 & 12.2 & 19.6 \\
\hline Mozambique & & 0.0 & 1.3 & 1.6 & 2.3 \\
\hline Namibia & & 0.0 & 0.1 & 1.0 & 1.7 \\
\hline New Zealand & 3 & & 0.4 & 0.6 & 0.9 \\
\hline Nicaragua & 9.2 & 8.8 & 1.5 & 4.4 & 6.5 \\
\hline Niger & & 5.5 & 1.0 & 4.2 & 6.3 \\
\hline Nigeria & & 1.3 & 4.2 & 6.0 & 8.3 \\
\hline Pakistan & 8.5 & & 23.7 & 45.2 & 55.4 \\
\hline Panama & 9.2 & 8.8 & 1.5 & 4.4 & 6.5 \\
\hline Paraguay & 0 & 0.0 & 0.5 & 0.9 & 1.5 \\
\hline Peru & 10.5 & 2.5 & 1.6 & 4.6 & 6.5 \\
\hline Philippines & 3 & & 1.7 & 5.4 & 7.4 \\
\hline Rwanda & & 0.0 & 25.0 & 57.9 & 94.3 \\
\hline Senegal & & 1.3 & 4.2 & 6.0 & 8.3 \\
\hline Sierra Leone & & 1.3 & 4.2 & 6.0 & 8.3 \\
\hline Singapore & 3 & & 0.1 & 3.0 & 4.2 \\
\hline South Africa & & 0.0 & 0.5 & 2.1 & 3.2 \\
\hline Sri Lanka & 8.5 & & 15.5 & 26.9 & 32.4 \\
\hline Sudan & & 0.5 & 14.0 & 4.6 & 6.4 \\
\hline Suriname & & 0.0 & 0.2 & 0.3 & 0.5 \\
\hline Swaziland & & 0.0 & 0.5 & 2.1 & 3.2 \\
\hline Tanzania & & 1.7 & 2.0 & 2.6 & 3.8 \\
\hline
\end{tabular}

Table 7: Appendix A: Urbanization aggd Population Density in 1500, continued 


\begin{tabular}{|c|c|c|c|c|c|}
\hline Country & $\begin{array}{r}\text { Urban (\%) } \\
\text { AJRR }\end{array}$ & Urban (\%) & $\begin{array}{r}\text { Population } \\
\text { Density }\end{array}$ & $\begin{array}{l}\text { Population } \\
\text { Density }\end{array}$ & $\begin{array}{l}\text { Population } \\
\text { Density }\end{array}$ \\
\hline Togo & & 1.3 & 4.2 & 6.0 & 8.3 \\
\hline Tunisia & 12.3 & 8.1 & 11.7 & 24.2 & 38.6 \\
\hline Uganda & & 0.0 & 7.5 & 10.6 & 15.3 \\
\hline Uruguay & 0 & 0.0 & 0.1 & 0.0 & 0.0 \\
\hline USA & 0 & 0.0 & 0.1 & 0.2 & 0.3 \\
\hline Venezuela & 0 & 0.0 & 0.4 & 0.7 & 1.0 \\
\hline Vietnam & 7.3 & & 6.1 & 17.3 & 25.6 \\
\hline Yemen & & & & 45000.0 & 112500.0 \\
\hline Zambia & & 0.0 & 0.8 & 1.1 & 1.7 \\
\hline Zimbabwe & & 0.0 & 0.8 & 1.1 & 1.7 \\
\hline
\end{tabular}

Table 8: Appendix A: Urbanization and Population Density in 1500, continued 


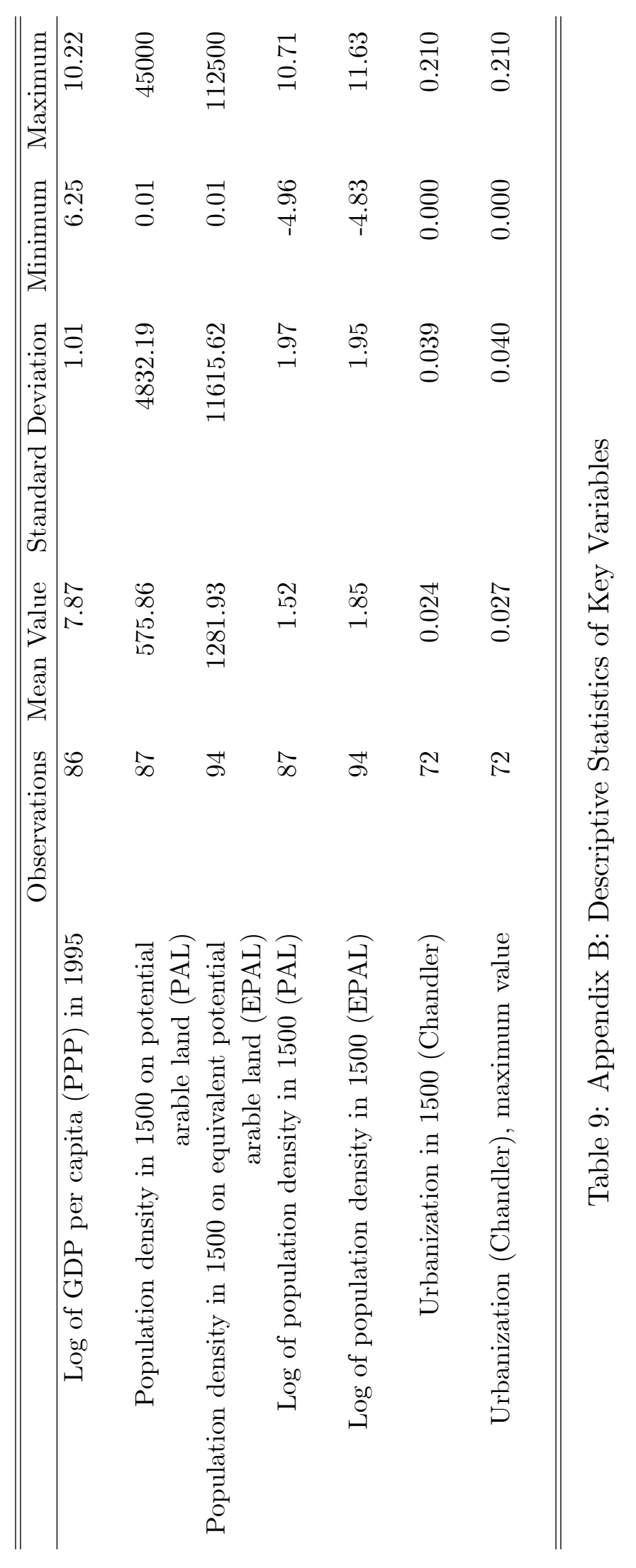

